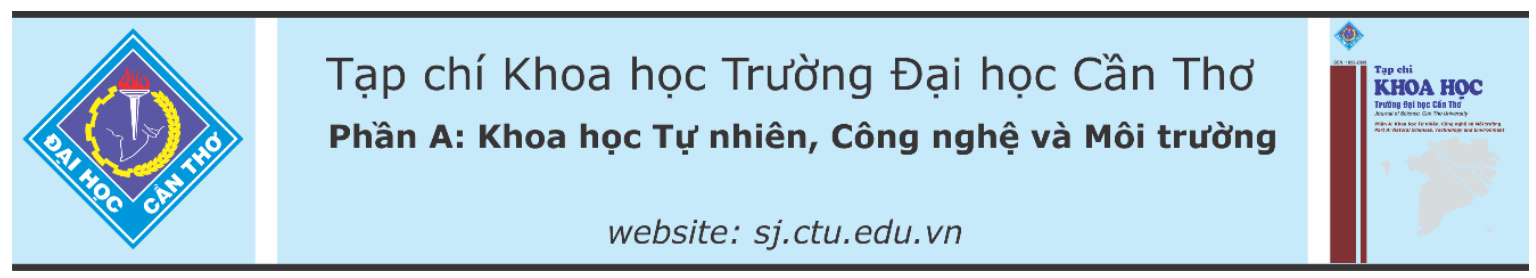

DOI:10.22144/ctu.jvn.2021.116

\title{
HIỆU QUẢ QUẢN LÝ TÀI NGUYÊN NƯớC MặT PHỤC VỤ SẢN XUẤT NÔNG NGHIỆP VÀ NUÔI TRỒNG THUỶ SẢN DƯỚI TÁC ĐộNG CỦA XÂM NHẬP MẬN TẠI TİNH BẾN TRE
}

\author{
Nguyễn Thị Thuý $\mathrm{Vy}^{1}$, Nguyễn Minh Tuấn ${ }^{2}$, Trần Hoàng Hiểu ${ }^{3}$, Lê Tấn Lợi ${ }^{1}$ và Văn Phạm Đăng Trí ${ }^{*}$ \\ ${ }^{1}$ Khoa Môi trường và Tài nguyên Thiên nhiên, Trương Đại học Cần Tho' \\ ${ }^{2}$ Phòng Tài nguyên và Môi truờng huyện Châu Thành, Hậu Giang \\ ${ }^{3}$ Hoc viện Chinh trị Khu vục IV \\ *Người chịu trách nhiệm về bài viết: Văn Phạm Đăng Trí (email: vpdtri@.ctu.edu.vn)
}

\section{Thông tin chung:}

Ngày nhận bài: $31 / 12 / 2020$

Ngày nhận bài sưa: 11/05/2021

Ngày duyệt đăng: 20/08/2021

\section{Title:}

Effectiveness of surface water resources management for agriculture and aquaculture in the context of saline intrusion in Ben Tre province

\section{Tù khóa:}

Hiệu quả quản lý, nông nghiệp, nuôi trồng thủy sản, vùng ven biển, xâm nhập mặn

\section{Keywords:}

Agriculture, aquaculture, coastal zones, effectiveness of management, saline intrusion

\section{ABSTRACT}

The increasing saline intrusion in coastal areas of the Vietnamese Mekong Delta has affected the management of surface water resources for agriculture and aquaculture. This study evaluated the effectiveness in dealing with saline intrusion during the dry season from late 2019 to early 2020 in Ben Tre, based on the principle of clear roles and responsibilities of stakeholders in the OECD (Organization for Economic Co-operation and Development) water resources governance framework. The data were collected through interviews with relevant staff from district authorities and analyzed by descriptive statistics, and GIS tools were used to edit and publish maps. The duration of salinity intrusion in the dry season from 2019 to 2020 was longer, and the spatial range of saline intrusion was wider than the 40-year average, resulting in severe freshwater scarcity and significant agricultural and aquaculture losses. The promulgation of guiding documents to cope with saline intrusion in agriculture and aquaculture was promptly implemented to eliminate saline intrusion driven damages. However, horizontal coordination among local stakeholders could still be limited.

\section{TÓM TẮT}

Xâm nhập mặn tại các vùng ven biển Đồng bằng sông Cửu Long ngày càng gia tăng, đã ảnh hưởng đến công tác quản lý nguồn tài nguyên nước mặt phục vu cho sản xuất nông nghiệp và nuôi trồng thủy sản. Nghiên cưu đánh giá tính hiệu quả trong công tác úng phó xâm nhập mặn vào mùa khô 2019-2020 tại tỉnh Bến Tre, dựa trên nguyên tắc về vai trò và trách nhiệm rõ ràng của các bên liên quan về quản trị tài nguyên nước của OECD (Tổ chức hợp tác và phát triến kinh tế). Các số liệu được thu thập thông qua các cuộc phỏng vấn cán bộ địa phuoong và được xư lý bằng phương pháp thống kê mô tả và công cu GIS được sư dụng để biên tập bản đồ. Thời gian xâm nhập mặn mùa khô năm 2019 - 2020 kéo dài và có phạm vi ảnh hưởng rộng hơn so với trung bìn 40 năm trở lại đây, điều này đã dẫn đến việc thiếu nguồn nuớc ngọt trầm trọng gây thiệt hại đáng kể đến sản xuất nông nghiệp và nuôi trồng thuỷ sản. Việc ban hành các văn bản chi đạo công tác ưng phó xâm nhập mặn trong sản xuất nông nghiệp và nuôi trồng thuỷ sản đã được thực hiện kịp thời. Tuy nhiên, sụ phổi hợp theo chiều ngang giữa các bên tham gia tại địa phuơng còn gặp hạn chế. 


\section{GIỚI THIẸU}

Đồng bằng sông Cửu Long (ĐBSCL) được xem là vùng sản xuất nông nghiệp $(\mathrm{SXNN})$ và nuôi trồng thuỷ sản (NTTS) lớn nhất Việt Nam và cùng với xu thế phát triển, nhu cầu sử dụng nước cho ngành nông nghiệp và NTTS ngày càng gia tăng. Được đánh giá là một trong ba đồng bằng lớn của thế giới bị đe dọa nghiêm trọng nhất bởi biến đổi khí hậu (Intergovernmental Panel on Climate Change, 2014), các tỉnh ven biển ĐBSCL đang phải đối mặt với tình trạng thiếu nguồn nước ngọt phục vụ cho hoạt động $\mathrm{SXNN}$ và NTTS vào mùa khô. Trong những năm gần đây, tình hình xâm nhập mặn tại các vùng ven biển diễn biến ngày càng gây gắt, gây nhiều khó khăn trong công tác quản lý nguồn tài nguyên nước mặt. Khung pháp lý về tài nguyên nước tại Việt Nam đã được xây dựng trong hơn hai thập kỷ qua và từng bước được hoàn chỉnh nhằm đáp ứng nhu cầu thực tiễn ngày càng đa dạng và biến động. Công tác quản lý tài nguyên nước tại Việt Nam đang được thực thi dựa trên Luật Tài nguyên nước (Luật số 17/2012/QH13) với các quy định về việc quản lý, bảo vệ, khai thác, sử dụng tài nguyên nước, phòng, chống và khắc phục hậu quả tác hại do nước gây ra trên lưu vực sông. Trước những ảnh hưởng của biến đổi khí hậu, đặc biệt là hạn - mặn đã làm ảnh hưởng đến hoạt động sản xuất và chất lượng cuộc sống của người dân, Quốc hội đã ban hành Luật Phòng, chống thiên tai $(33 / 2013 / \mathrm{QH} 13)$ với các quy định về hoạt động phòng, chống thiên tai, quản lý nhà nước, quyền và nghĩa vụ của các bên liên quan trong việc tham gia hoạt động phòng, chống thiên tai. Nhằm hỗ trợ cho việc thực thi các Luật, Chính phủ đã ban hành các văn bản như: Nghị định số 201/2013/NĐ-CP (ngày 21/11/2013) về Quy định chi tiết thi hành một số điều của Luật Tài nguyên nước; Nghị định số 66/2014/NĐ-CP (ngày 04/07/2014) về Quy định chi tiết, hướng dẫn thi hành một số điều của Luật Phòng, chống thiên tai; Nghị quyết số 76/NQ-CP (ngày 18/06/2018) về công tác phòng, chống thiên tai nhằm nâng cao năng lực, chủ động phòng, chống thiên tai, thích ứng với biến đổi khí hậu trước tình hình thiên tai ngày càng diễn biến phức tạp. Tuy nhiên, quản trị nước tại Việt Nam hiện vẫn chưa đáp ứng các tiêu chuẩn cần thiểt để có thể triển khai công tác quản lý nước tổng hợp và bền vững (World Bank, 2019). Thực tế cho thấy

\footnotetext{
${ }^{1}$ Nhóm Tài nguyên Nước 2030 là một đối tác đặc biệt giũua nhà nước - khối tư nhân - các tổ chức xã hội dân sụ nhằm giúp các chính phủ thúc đẩy nhũng cải cách nhằm đảm bảo quản lý tài nguyên nước một cách bền
}

cơ cấu thể chế cho quản lý tài nguyên nước đã được Luật Tài nguyên nước (2012) quy định rõ, thế nhưng để tất cả các bên liên quan ở cấp ngành và cấp địa phương làm việc cùng nhau còn là một thách thức lớn (Jakob \& Khemka, 2017) ${ }^{1}$, theo đó, để giảm mức độ căng thẳng về nước trong một lưu vực, cần có 24 biện pháp từ 7 Bộ, 6 Hội đồng cấp Tỉnh/Thành, các công ty thủy lợi và các doanh nghiệp tư nhân, cùng hàng triệu nông dân và cư dân thành phố (Jakob \& Khemka, 2017).

Hiện nay, các khung đánh giá trong lĩnh vực quản trị tài nguyên nước đã được sử dụng ở một số quốc gia với mục tiêu cung cấp một số tiêu chí đánh giá, điển hình như: (i) mười khối thành phần xây dựng hệ thống quản trị tài nguyên nước bền vững (van Rijswick et al., 2014); (ii) các phương pháp tiếp cận bền vững FIETS (Finance: tài chính; Institution: thể chế; Environment: môi trường; Technology: công nghệ; và Society: xã hội) (Dutch WASH Alliance, 2014); và (iii) các nguyên tắc của tổ chức hợp tác và phát triển kinh tế (Organization Economic Co-operation and Development - OECD) về quản trị tài nguyên nước (OECD, 2015). Từ năm 2010, OECD đã cung cấp các nghiên cứu về những lỗ hổng quản trị cản trở việc thiết kế và thực thi chính sách về tài nguyên nước, đồng thời đề xuất một số các giải pháp chính sách và thực tiễn tốt để khắc phục về vấn đề trên $(\mathrm{OECD}, 2015)$. Theo OECD (2015), không có giải pháp quản trị chung nào phù hợp cho tất cả các thách thức về nước trên toàn thế giới do sự đa dạng của các tình huống trong và trên khắp các quốc gia. Các nguyên tắc của OECD cung cấp một khuôn khổ để đánh giá sự hoàn chỉnh của hệ thống quản trị tài nguyên nước. Bên cạnh đó, các nguyên tắc của $\mathrm{OECD}$ về quản trị nước được xây dựng dựa trên các thách thức về nước trên toàn thế giới; vì thế tùy thuộc vào mục đích và điều kiện nghiên cứu mà các nguyên tắc cần được lựa chọn phù hợp (OECD, 2015). Nguyên tắc của OECD được chia làm 12 nguyên tắc thuộc 3 nhóm (Hình 1): Hiệu quả, Hiệu suất và Niềm tin và sụ tham gia. Cụ thể, để thực hiện được các giải pháp cần phải xác định, triển khai các mục tiêu chính sách rõ ràng về sử dụng nước bền vững ở các cấp chính quyền, và đạt được các mục tiêu đã đề ra (hiệu quả). Ngoài ra, các lợi ích của việc quản lý nước bền vững và phúc lợi cần phải được mở rộng tối đa với chi phí thấp nhất cho xã hội (hiệu suất). Cuối cùng, cần phải

vũng cho sụ phát triển kinh tế xã hội lâu dài của quốc gia. Nhóm 2030 WRG được công bố thành lạp vào năm 2008 tại Diễn đàn Kinh tế Thế giới, được Tồ chức Tài chính Quốc tế (IFC) chủ trì tù năm 2012. 
xây dựng niềm tin trong cộng đồng, đồng thời cần đảm bảo sự tham gia của tất cả các bên liên quan thông qua sự công khai dân chủ và công bằng cho toàn xã hội (niềm tin và sụ tham gia). Trong nhóm thứ nhất (hiệu quả) bao gồm bốn nguyên tắc Hình 1, nguyên tắc thứ nhất là "vai trò và trách nhiệm rõ ràng của các bên liên quan" là bước đầu tiên dùng để kiểm tra vai trò và trách nhiệm của các tổ chức quản lý đã được quy định rõ ràng, đó là cơ sở để đánh giá việc thực thi hiệu quả các chính sách được đề ra.

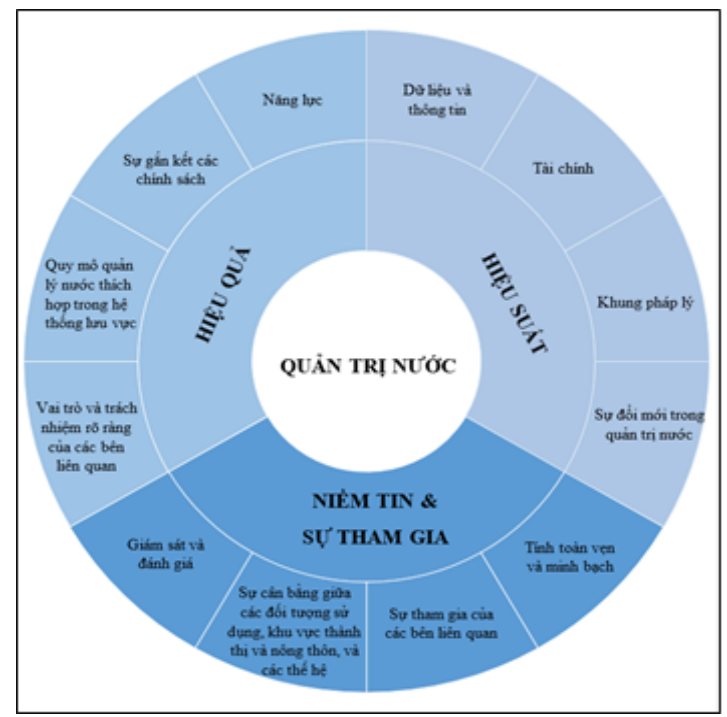

Hình 1. Các nguyên tắc của $\mathrm{OECD}$ về quản trị nước (OECD, 2015)

Bến Tre là một trong những tỉnh hạ lưu sông Mekong, giáp với biển Đông và có hệ thống sông ngòi dày đặc, bao gồm bốn con sông chính là sông Tiền Giang, Ba Lai, Hàm Luông và Cổ Chiên. Mạng lưới sông ngòi dày đặc đã tạo điều kiện thuận lợi cho việc cung cấp nguồn nước tưới cho $\mathrm{SXNN}$; tuy vậy, đây cũng là trở ngại đáng kể khi vào mùa khô lưu lượng từ thượng nguồn đổ về giảm kết hợp với thủy triều dẫn đến việc mặn xâm nhập sâu vào trong các kênh nội đồng. Từ cuối năm 2019 đến đầu năm 2020, Bến Tre là một trong những tỉnh chịu tác động nặng nề từ tình hình xâm nhập mặn. Trước tình hình xâm nhập mặn ngày càng gia tăng, việc đề xuất các giải pháp quản lý nhà nước về ứng phó với xâm nhập mặn của một số ngành và địa phương còn mang tính tạm thời ngắn hạn; do đó, nghiên cứu được thực hiện với mục tiêu đánh giá tác động của xâm nhập mặn đến hiện trạng hệ thống SXNN và NTTS tại tỉnh Bển Tre cũng như đánh giá hiệu quả công tác ứng phó xâm nhập mặn trong $S X N N$ và NTTS giai đoạn mùa khô 2019 - 2020.

\section{PHƯƠNG PHÁP NGHIÊN CÚU}

\section{1. Đối tượng và phạm vi nghiên cứu}

Nghiên cứu được thực hiện tại các huyện Châu Thành, Giồng Trôm và Thạnh Phú, tỉnh Bến Tre (Hình 2); đây là 03 huyện đại diện cho 03 vùng sinh thái (ngọt - lợ - mặn) nằm trong định hướng phân vùng sử dụng đất đai đến năm 2020 của tỉnh Bến Tre với các loại hình SXNN khác nhau (cây lâu năm, cây ăn trái, cây lúa) và NTTS. Nghiên cứu thực hiện trong giai đoạn từ tháng 11 năm 2019 đến tháng 6 năm 2020 và đối tượng nghiên cứu là tình trạng xâm nhập mặn đối với nguồn tài nguyên nước mặt, SXNN và NTTS tại vùng nghiên cứu.

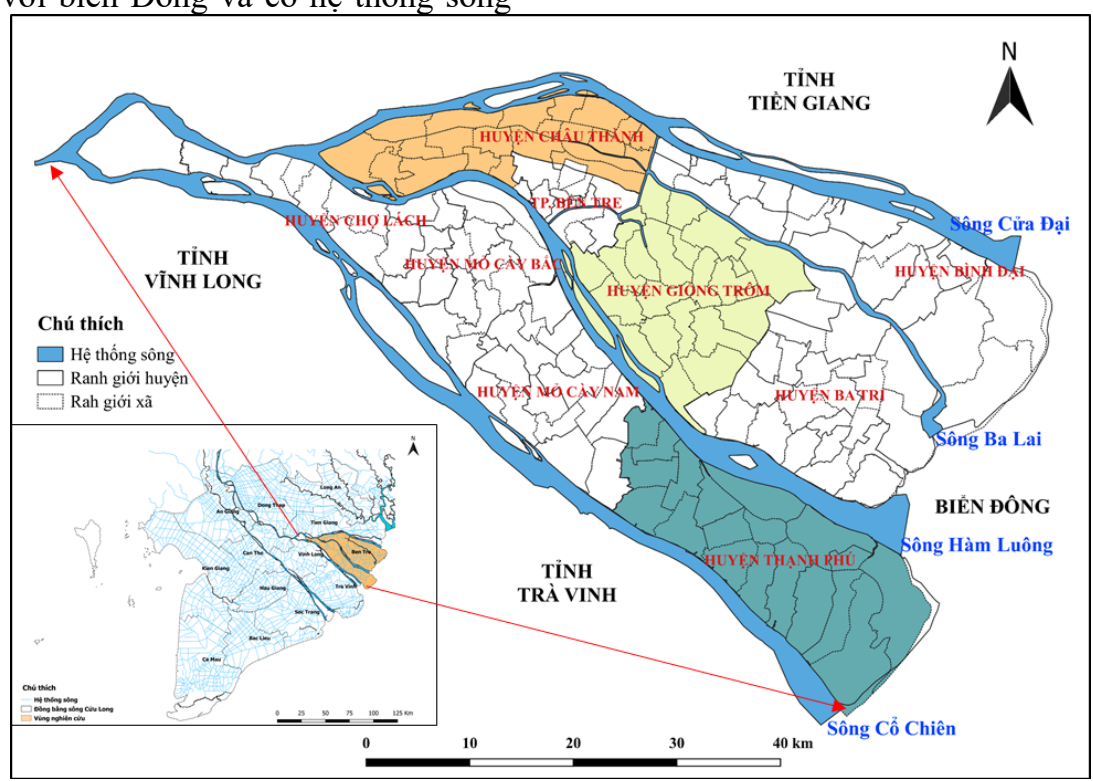

Hình 2. Phạm vi nghiên cứu 


\subsection{Phương pháp thu thập số liệu}

\subsubsection{Thu thập số liệu thứ cấp}

Các số liệu thứ cấp được phục vụ cho nghiên cứu bao gồm:

- Các dự báo, báo cáo tổng quan về tình hình xâm nhập mặn và dữ liệu mặn tại các trạm quan trắc trên địa bàn tỉnh Bến Tre từ tháng 11/2019 đến tháng 06/2020 được thu thập tại Đài Khí tượng Thuỷ văn tỉnh Bến Tre.

- Bản đồ điều chỉnh quy hoạch sử dụng đất đai tỉnh Bến Tre giai đoạn 2016 - 2020, Báo cáo kế hoạch sử dụng đất đai tỉnh Bến Tre giai đoạn 2016 - 2020 và bản đồ ranh mặn tỉnh Bến Tre mùa khô năm 2019 - 2020 được thu thập tại Sở Tài nguyên và Môi trường (TN\&MT) tỉnh Bến Tre.

- Báo cáo kiểm kê đất đai năm 2019 được thu thập từ Phòng TN\&MT các huyện Châu Thành, Giồng Trôm và Thạnh Phú.

- Báo cáo kết quả phòng, chống và ứng phó xâm nhập mặn mùa khô năm 2019 - 2020 được thu thập từ Phòng Nông nghiệp và Phát triển Nông thôn (NN\&PTNT) tại các huyện Châu Thành, Giồng Trôm và Thạnh Phú.

- Các văn bản chỉ đạo phòng, chống và ứng phó xâm nhập mặn mùa khô năm 2019 - 2020 thu thập tại Ủy ban nhân dân (UBND) tỉnh Bến Tre và UBND các huyện Châu Thành, Giồng Trôm và Thạnh Phú.

\subsubsection{Thu thập số liệu sơ cấp}

Nghiên cứu thu thập các số liệu sơ cấp từ 06 cuộc phỏng vấn trực tiếp cán bộ chuyên trách đại diện Phòng TN\&MT và Phòng NN\&PTNT theo phương pháp phỏng vấn người am hiểu (Ryan et al., 2009) với nội dung: (i) thực trạng diễn biến xâm nhập mặn trên các sông chính tại địa phương cuối năm 2019 và 06 tháng đầu năm 2020; (ii) tác động của xâm nhập mặn đến việc SXNN và NTTS tại địa phương; và (iii) công tác ứng phó xâm nhập mặn tại các huyện bao gồm: các giải pháp ứng phó và kết quả ứng phó với xâm nhập mặn tại địa phương.

\subsection{Xử lý số liệu}

Các số liệu sơ cấp và thứ cấp sau khi thu thập được xử lý bằng phương pháp thống kê mô tả các tác động của xâm nhập mặn mùa khô năm 2019 2020 đến SXNN và NTTS, sự phối hợp giữa các bên liên quan trong công tác ứng phó xâm nhập mặn. Công cụ GIS được sử dụng để biên tập các bản đồ.
Bên cạnh đó, các số liệu còn được thể hiện dưới dạng bản đồ, sơ đồ và biểu bảng để phục vụ cho việc đánh giá ảnh hưởng của xâm nhập mặn đến SXNN và NTTS và tính kịp thời trong công tác ứng phó xâm nhập mặn tại địa phương.

\subsection{Phương pháp đánh giá hiệu quả công tác ứng phó xâm nhập mặn}

Trong nghiên cứu này, nguyên tắc thứ nhất của OECD là "vai trò và trách nhiệm của các bên liên quan" thuộc nhóm thứ nhất (Hiệu quả) được sử dụng để đánh giá hiệu quả của công tác ứng phó xâm nhập mặn trong SXNN và NTTS (OECD, 2015). Nguyên tắc này nêu lên việc phân chia và nhận định vai trò và trách nhiệm trong việc hoạch định chính sách về nguồn nước, thực thi chính sách, quản lý việc vận hành và thúc đẩy sự hợp tác giữa các bên có trách nhiệm. Tiêu chí được đặt ra để đánh giá tính hiệu quả của công tác quản lý tài nguyên nước mặt trong nguyên tắc này là sự tồn tại và múc độ thực thi luật và các quy định nhà nước có liên quan đến quản lý tài nguyên nước nhằm ứng phó với xâm nhập mặn tại địa phương bao gồm:

Xác định sự tồn tại của các văn bản quy định về vai trò và trách nhiệm của các bên liên quan trong công tác ứng phó xâm nhập mặn tại địa phương được đánh giá thông qua việc các văn bản chỉ đạo ứng phó xâm nhập mặn được ban hành từ Trung ương đến địa phương;

Đánh giá mức độ thực thi các văn bản chỉ đạo tại địa phương trên cơ sở xem xét thực trạng sự phối hợp giữa các bên liên quan tại địa phương thông qua sự phối hợp trong việc ban hành các văn bản chỉ đạo ứng phó xâm nhập mặn từ Trung ương đến địa phương và sự phối hợp giữa các Sở/ban/ngành (cấp tỉnh), các phòng/ban (cấp huyện) trong việc thực thi văn bản nhằm đánh giá tính kịp thời trong công tác ứng phó xâm nhập mặn tại địa phương (dựa vào thời gian ban hành văn bản theo Tiêu chuẩn Việt Nam 9001:2015 về Quy trình xử lý văn bản (Ủy ban Dân tộc, 2019).

\section{KẾT QUẢ VÀ THẢO LUẬN}

\subsection{Tác động của xâm nhập mặn mùa khô năm 2019 - 2020 đến hiện trạng SXNN và NTTS trên địa bàn tỉnh Bến Tre}

Tình trạng xâm nhập mặn vào mùa khô hàng năm tại các vùng ven biển ĐBSCL phụ thuộc vào hai yếu tố chính là lưu lượng thượng nguồn đổ về ĐBSCL và thuỷ triều từ Biển Đông (Giáp Văn Vinh, 2020). Theo dữ liệu thuỷ văn từ Uỷ hội sông Mekong Việt Nam, dòng chảy trên sông Mekong đổ về ĐBSCL mùa khô năm 2019 - 2020 thiếu hụt so 
với trung bình nhiều năm thời kỳ từ năm 1980 2020 (Viện Khoa học Thuỷ lợi miền Nam 2019) vì thế xâm nhập mặn xuất hiện từ rất sớm tại các cửa sông. Phạm vi xâm nhập mặn cao nhất của các tháng với nồng độ từ $4 \mathrm{~g} / \mathrm{L}$ trở lên trên các sông chính tỉnh Bến Tre (Hình 3) cho thấy xâm nhập mặn đã xuất hiện từ giữa tháng 11/2019 với phạm vi khoảng 24 $-34 \mathrm{~km}$ tính từ cửa sông. Theo báo cáo từ Đài Khí tượng Thuỷ văn tỉnh Bến Tre, đến tháng 12/2019 mặn xâm nhập diễn ra nhanh và tiến sâu vào nội đồng, sang tuần thứ 3 của tháng 12/2019 phạm vi xâm nhập mặn trên sông Hàm Luông (khoảng 60 km) ở mức sâu hơn tháng 02 năm 2016 và trên sông Cửa Đại (khoảng $45 \mathrm{~km}$ ) ở mức tương đương cùng kỳ năm 2015. Vào tuần đầu tiên tháng $01 / 2020$, phạm vi xâm nhập mặn sâu nhất trên các sông chính tương đương xâm nhập mặn tháng 02/2016. Đến tháng 02/2020, hệ thống sông chính trên địa bàn Tỉnh đã hoàn toàn nhiễm mặn với khoảng cách từ 64 - $86 \mathrm{~km}$ tính từ cửa sông, độ mặn và mức độ xâm nhập của nước mặn đã cao hơn năm 2015 - 2016. Mặn xâm nhập sâu và duy trì qua các tháng cùng với hệ thống công trình thủy lợi trên địa bàn tỉnh Bến Tre chưa hoàn toàn khép kín dẫn đến việc mặn xâm nhập sâu vào trong các kênh nội đồng, gây thiếu nguồn nước ngọt phục vụ cho $\mathrm{SXNN}$ và sinh hoạt của người dân tại địa phương. Mặn đã tràn qua các kênh rạch xâm nhập vào sâu nội đồng gây nhiều thiệt hại đến SXNN và NTTS tại địa phương.

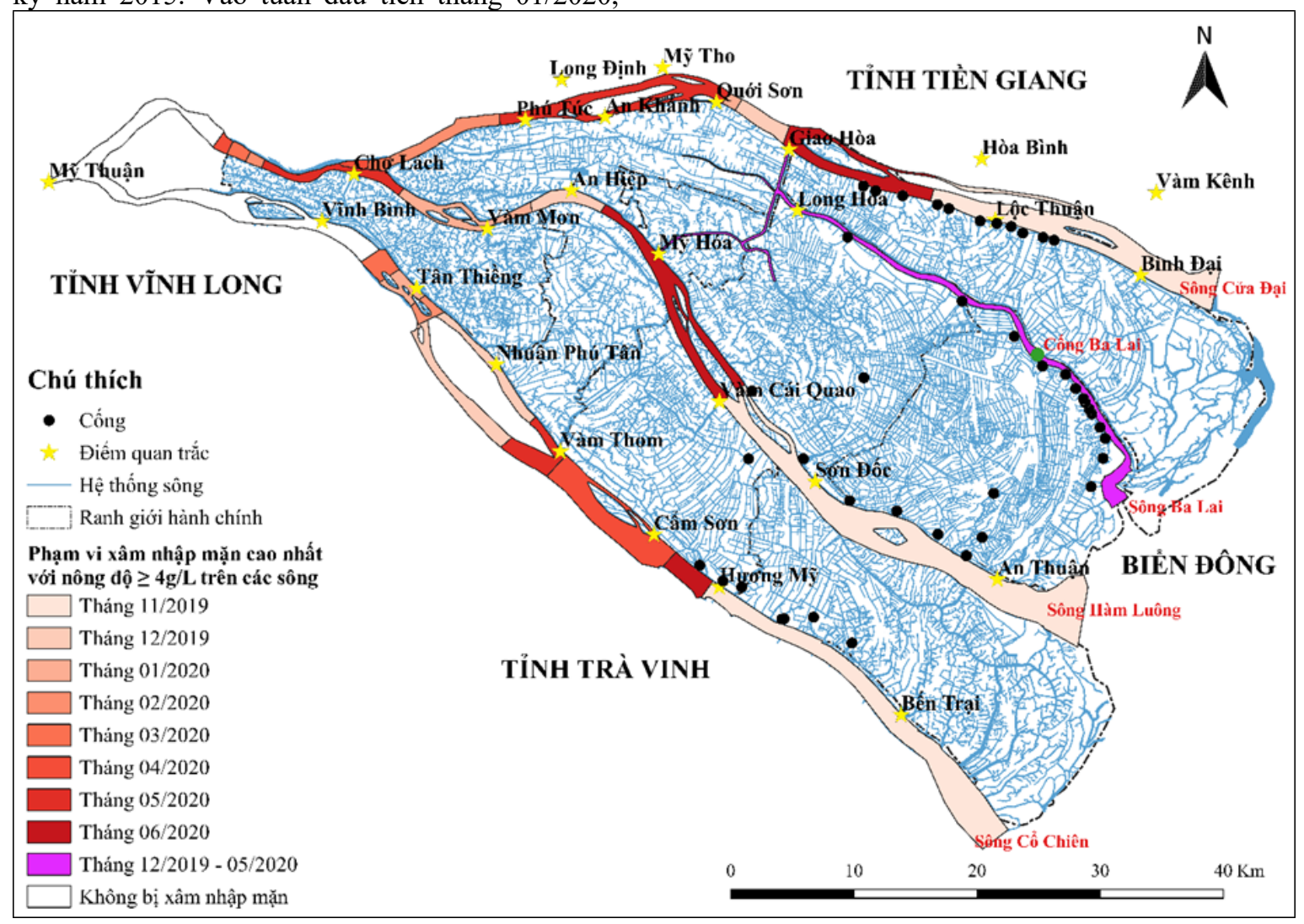

Hình 3. Phạm vi xâm nhập mặn cao nhất với nồng độ $\geq 4 \mathrm{~g} / \mathrm{L}$ từ tháng $11 / 2019-06 / 2020$ tại các sông trên địa bàn tỉnh Bến Tre

(Nguồn: Đài Khí tượng Thủy văn tỉnh Bến Tre, 2020)

Nội dung chủ động ứng phó biến đổi khí hậu, nước biển dâng theo định hướng phát triển bền vững được chú trọng trong báo cáo điều chỉnh quy hoạch sử dụng đất đển năm 2020 và kế hoạch sử dụng đất kỳ cuối $(2016$ - 2020) trên địa bàn tỉnh Bến Tre. Toàn tỉnh được định hướng phân vùng theo đặc tính tài nguyên nước (ngọt - lợ - mặn), bao gồm vùng ngọt, vùng lợ và vùng mặn. Vùng ngọt gồm toàn bộ diện tích huyện Chợ Lách và các xã phía Tây huyện Châu Thành và huyện Mỏ Cày Bắc với đặc trưng các loại cây ăn trái; đây là khu vực trọng điểm phát triển nghề trồng hoa kiểng, sản xuất giống cây ăn trái. Vùng lợ gồm các xã phía Đông huyện Châu Thành, Mỏ Cày Bắc, toàn bộ thành phố Bến Tre, 
huyện Giồng Trôm, Mỏ Cày Nam, các xã phía Tây huyện Bình Đại, một phần diện tích thuộc huyện Ba Tri và Thạnh Phú; đây là vùng phát triển kinh tế nông nghiệp đa dạng, trong đó chủ yếu phát triển vườn dừa và kết hợp cây ăn trái NTTS xen canh trong vườn. Vùng mặn tập trung ở 3 huyện ven biển Bình Đại, Ba Tri và Thạnh Phú; đây là vùng tập trung chuyên canh và luân canh tôm nước lợ - mặn, luân canh lúa - tôm bên cạnh việc phát triển mô hình nuôi nghêu, sò ở một số khu vực bãi triều kết hợp với khai thác muối (Hình 4).

Huyện Châu Thành là vùng chuyên trồng các loại cây ăn trái của tỉnh Bến Tre, với khả năng cung cấp nước ngọt gần như quanh năm. Mô hình canh tác chủ yếu của huyện năm 2020 là cây ăn trái (sầu riêng, chôm chôm, bưởi da xanh) và cây dừa. Mặc dù nằm trong vùng sinh thái nước ngọt nhưng xâm nhập mặn mùa khô năm 2019 - 2020 vẫn gây ảnh hưởng đến nông nghiệp trên địa bàn huyện, có khoảng 7.995 ha dừa bị ảnh hưởng về năng suất, trong đó mức thiệt hại từ 30 - 70\% khoảng 954,4 ha. Diện tích cây ăn trái trên địa bàn huyện là 7.831 ha; trong đó, thiệt hại từ $30-70 \%$ diện tích 2.917,55 ha và thiệt hại trên $70 \%$ diện tích $1.212,49$ ha. Diện tích NTTS từ tháng $02 / 2020$ bị ảnh hướng từ độ mặn và phạm vi xâm nhập mặn tăng cao, nên người dân không phát triển diện tích nuôi cá, diện tích nuôi thủy sản đến nay là 26,5 ha. Đa số các diện tích nuôi cá theo hộ gia đình đều bị ảnh hưởng thiệt hại, nhất là khu vực các xã phía đông và các xã vùng ven sông Hàm Luông do độ mặn cao.

Huyện Giồng Trôm là huyện nằm giữa sông Hàm Luông và sông $\mathrm{Ba}$ Lai nằm trong vùng sinh thái nước lợ với 06 tháng nước ngọt và 06 tháng nước mặn. Các loại hình canh tác chủ yếu của huyện theo thứ tự là cây lâu năm (chủ yếu là dừa) và diện tích cây ăn trái (cây có múi: bưởi, chanh, quýt, cam) và diện tích lúa. Vùng trồng lúa bao gồm các xã: Bình Thành, Bình Hoà và Tân Thạnh giáp với huyện Ba Tri là vùng chuyên sản xuất lúa của huyện. Các xã còn lại của huyện là vùng trồng cây ăn trái và cây lâu năm. Riêng hai khu vực cồn Phước Long và cồn Hưng Long đã chuyển đổi mô hình canh tác từ năm 2017 từ trồng dừa sang NTTS do tác động từ xâm nhập mặn. Do hệ thống công trình thủy lợi huyện chưa hoàn toàn khép kín nên mặn vẫn xâm nhập qua các kênh, tràn qua các mương ảnh hưởng đến nông nghiệp của huyện. Xâm nhập mặn mùa khô năm 2019 - 2020 đã ảnh hưởng đến lúa vụ 3 tại huyện. Theo báo cáo từ Hội nghị tổng kết công tác phòng chống hạn mặn năm 2019 - 2020 của huyện Giồng Trôm thống kê tình hình thiệt hại trên các loại cây trồng, khoảng 958 ha lúa bị thiệt hại với mức độ thiệt hại trên $70 \%$; cây ăn trái thiệt hại từ 30 đến $70 \%$ khoảng 1.803 ha, thiệt hại trên $70 \%$ khoảng 2.033 ha; diện tích rau màu thiệt hại trên $70 \%$ khoảng 60 ha; diện tích nuôi cá da trơn thâm canh bị thiệt hại $30 \%$ đến $70 \%$ khoảng 18 ha.

Huyện Thạnh Phú có vị trí nằm giáp biển Đông thuộc vùng sinh thái nước mặn với thời gian nước mặn duy trì từ 08 tháng đến 12 tháng, huyện được chia thành 03 tiểu vùng phát triển kinh tế. Tiểu vùng 1 (vùng ngọt) bao gồm các xã nằm giáp với huyện Mỏ Cày Nam, hiện tại tập trung nuôi tôm nước ngọt và chuyển đổi cơ cấu cây trồng từ lúa sang cây lâu năm (chủ yếu là cây dừa) và cây ăn trái. Tuy nhiên, theo quy hoạch vùng này vẫn còn trồng lúa nhưng thực tế còn rất ít hộ dân trồng lúa tại xã Nghĩa An, Thị trấn Thạnh Phú và xã Mỹ Hưng (xã Quới Điền và Hoà Lợi canh tác lúa 2 vụ), nguyên nhân dẫn đến việc chuyển đổi cơ cấu cây trồng là do lợi nhuận kinh tế và cây lâu năm có khả năng chịu mặn cao hơn cây lúa. Tiểu vùng 2 (vùng lợ) có loại hình canh tác chính là xen canh 1 vụ nuôi tôm và 1 vụ lúa trên năm nằm ở các xã Mỹ $\mathrm{An}$ và $\mathrm{An}$ Thuận và một phần cây ăn trái. Tiểu vùng 3 (vùng mặn) chuyên về NTTS là các xã còn lại của vùng nằm giáp biển Đông. Với vị trí địa lý tiếp giáp biển, huyện Thạnh Phú bị ảnh hưởng xâm nhập mặn từ rất sớm, làm ảnh hưởng lớn đến SXNN và NTTS trên địa bàn huyện. Diện tích nuôi tôm càng xanh bị thiệt hại trên $70 \%$ khoảng 2.374 ha, tình hình thiệt hại tập trung chủ yếu vào tháng $02-03 / 2020$; diện tích nuôi cá bị ảnh hưởng (chủ yếu cá nước ngọt) thiệt hại trên $70 \%$ là 83 ha. Thiệt hại trên các loại cây trồng, trong đó diện tích thiệt hại trên $70 \%$ là 19,05 ha; diện tích thiệt hại từ $30-70 \%$ là $2.994,02$ ha chủ yếu là diện tích rau màu, cây ăn quả và cây dừa. 


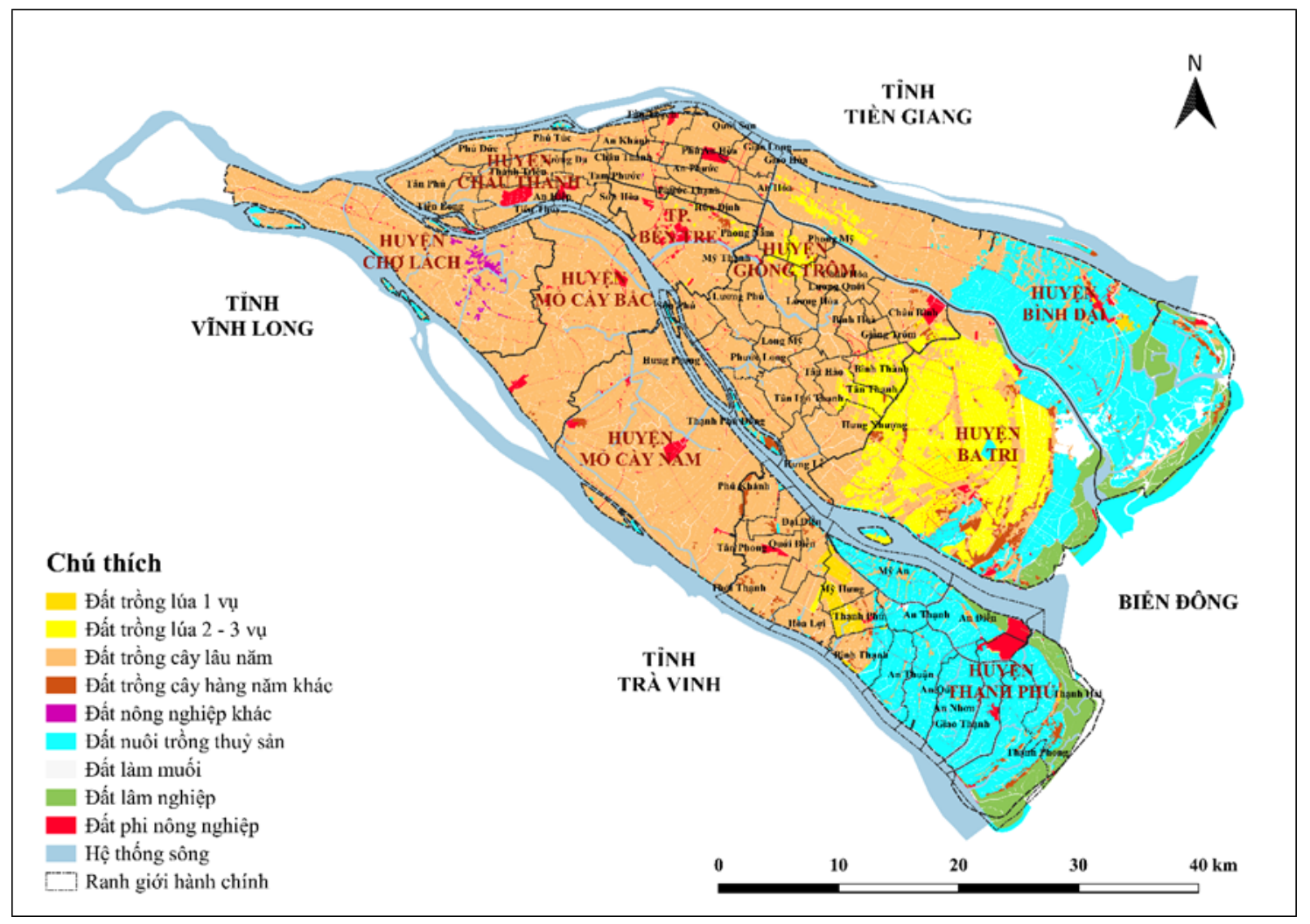

Hình 4. Bản đồ quy hoạch sử dụng đất đai giai đoạn 2016 - 2020 tỉnh Bến Tre (điều chỉnh năm 2016)

\section{(Nguồn: Sở Tài nguyên và Môi truờng tỉnh Bến Tre, 2018)}

Các huyện tại khu vực nghiên cứu đều chịu ảnh hưởng của xâm nhập mặn mùa khô năm 2019 2020, làm thiệt hại nghiêm trọng đến nông nghiệp và NTTS. Trước những tác động từ xâm nhập mặn gây khó khăn về nguồn nước ngọt phục vụ cho hoạt động canh tác, việc sử dụng đất đai tại địa phương đã có sự thay đổi từ năm 2015 đến năm 2020 (Bảng 1), các huyện đã dần chuyển đổi mô hình canh tác như huyện Thạnh Phú đã giảm diện tích trồng lúa chuyển sang trồng các loại cây có múi chịu được độ mặn cao hơn; huyện Giồng Trôm bên cạnh việc giảm diện tích đất trồng lúa chuyển sang trồng cây chịu được hạn - mặn, huyện đã bắt đầu phát triển nuôi trồng thủy sản tại các cù lao; huyện Châu Thành đã chuyển đổi dần đất trồng lúa từ năm 2015 sang cây lâu năm và các loại cây có múi chịu được hạn - mặn nhằm thích ứng với tình hình biến đổi khí hậu ngày càng tăng. Nhìn chung, các mô hình SXNN và NTTS đã chịu nhiều ảnh hưởng từ tác động của xâm nhập mặn (Phan Thanh Vũ và ctv., 2016). Theo (Le et al., 2018), xâm nhập mặn đã tác động đến hoạt động canh tác lúa dẫn đến việc phải thay đổi mô hình canh tác để thích ứng với xâm nhập mặn. Xâm nhập mặn không chỉ tác động đến các loại hình canh tác vùng sinh thái nước ngọt mà còn gây thiệt hại đến NTTS ở vùng sinh thái nước lợ, mặn.

Bảng 1. Diện tích đất trồng lúa thay đổi qua các năm tại khu vực nghiên cứu (ĐVT: ha)

\begin{tabular}{lrrrrr}
\hline Huyện Năm & $\mathbf{2 0 1 4}$ & $\mathbf{2 0 1 5}$ & $\mathbf{2 0 1 6}$ & $\mathbf{2 0 1 7}$ & $\mathbf{2 0 1 9}$ \\
\hline Châu Thành & 705 & 1.215 & 179 & 117 & 0 \\
Giồng Trôm & 9.225 & 8.766 & 2.757 & 7.284 & 954 \\
Thạnh Phú & 10.659 & 9.111 & 7.295 & 8.505 & 6.330 \\
\hline
\end{tabular}

(Nguồn: Phòng TN\&MT huyện Châu Thành, huyện Giồng Trôm và huyện Thạnh Phú, 2019) 


\section{2. Đánh giá hiệu quả công tác quản lý nguồn tài nguyên nước mặt khu vực nghiên cứu}

3.2.1. Sư tồn tại của các văn bản quản lý nhà nuớc trong công tác ưng phó xâm nhập mặn

Tại Việt Nam, công tác quản lý nhà nước về ứng phó thiên tai đang được thực thi dựa trên Luật Phòng, chống thiên tai (2013) và các văn bản dưới hướng dẫn thi hành luật. Căn cứ vào Luật và các văn bản dưới luật đã được ban hành, các văn bản về ứng phó xâm nhập mặn mùa khô năm 2019 - 2020 đã được ban hành từ cấp Trung ương đến địa phương (Hình 5). Thủ tướng Chính phủ đã ban hành Thông báo số 247/TB-VPCP (ngày 16/07/2019) giao nhiệm vụ về phòng, chống xâm nhập mặn cho các bộ, ngành, cơ quan trung trương và chính quyền các cấp ở địa phương. Đến tháng 01/2020, tình hình xâm nhập mặn diễn ra gay gắt hơn so với những dự báo, Thủ tướng Chính phủ ban hành Chỉ thị số 04/CTTTg (ngày 22/01/2020) giao nhiệm vụ cho các Bộ và UBND các tỉnh phối hợp với nhau triển khai các giải pháp cấp bách phòng, chống hạn hán, thiếu nước, xâm nhập mặn để đảm bảo nguồn nước ngọt phục vụ cho sản xuất và dân sinh. Ban Chỉ đạo Trung ương về phòng, chống thiên tai là cơ quan chỉ đạo, chỉ huy về phòng, chống thiên tai (được quy định tại Điều 44, Luật Phòng, chống thiên tai) ban hành công văn số 98/TTPCTT triển khai nội dung trong văn bản chỉ đạo từ Thủ tướng Chính phủ. Ngoài ra, Bộ NN\&PTNT là cơ quan thường trực của Ban Chỉ đạo Trung ương về phòng, chống thiên tai đã ban hành một số văn bản như: Công văn số 6708/BNN/TCTL (ngày 12/09/2019) giao nhiệm vụ cho UBND các tỉnh về việc chuẩn bị triển khai công tác phòng, chống xâm nhập mặn mùa khô năm 2019 - 2020; Chỉ thị số 8008/CT-BNN-TCTL (ngày 25/10/2019) giao nhiệm vụ cho UBND các tỉnh, các cơ quan trực thuộc Bộ NN\&PTNT tổ chức thực hiện các giải pháp cụ thể được nêu trong chỉ thị nhằm đảm bảo nguồn nước phục vụ cho sản xuất; Công văn số $741 / \mathrm{BNN}-\mathrm{TCTL}$ (ngày 03/02/2020) nhằm triển khai thực hiện Chỉ thị 04/CT-TTg của Thủ tướng Chính phủ. Bên cạnh đó, các tổng cục, các viện trực thuộc Bộ NN\&PTNT cũng đã có các văn bản dự báo và cảnh báo về nguồn nước và tình hình xâm nhập mặn mùa khô năm 2019 - 2020.

Nhiệm vụ của các bên liên quan trong công tác ứng phó xâm nhập mặn mùa khô năm 2019 - 2020 tại tỉnh Bến Tre đã được UBND tỉnh Bến Tre quy định tại Kế hoạch số 4741/KH-UBND (ngày 29/09/2019) về việc phòng chống thiếu nước, hạn hán, xâm nhập mặn mùa khô năm 2019 - 2020, nhằm chủ động ứng phó và đảm bảo đủ nước ngọt phục vụ nhu cầu sinh hoạt và sản xuất của người dân, doanh nghiệp trên địa bàn tỉnh. Theo văn bản này, UBND Tỉnh đã giao nhiệm vụ Sở NN\&PTNT, UBND các huyện và thành phố đảm bảo thực hiện tốt công tác cảnh báo và dự báo diễn biến xâm nhập mặn, hướng dẫn người dân các biện pháp phòng, chống và ứng phó trong các lĩnh vực trồng trọt, chăn nuôi và NTTS. Đưa ra lịch thời vụ phù hợp với từng vùng và theo dõi tình hình xâm nhập mặn để chủ động lấy nước ngọt phục vụ sản xuât; UBND các huyện phối hợp với Sở NN\&PTNT, Công ty trách nhiệm hữu hạn Một thành viên Khai thác Công trình Thủy lợi tổ chức kiểm tra, rà soát hệ thống công trình thủy lợi tại địa phương, đắp đập thời vụ ngăn mặn cục bộ. Ngoài các văn bản chỉ đạo được ban hành, thông qua cuộc Hội nghị phòng, chống hạn hán, xâm nhập mặn đảm bảo sản xuất nông nghiệp và dân sinh khu vưc ĐBSCL mùa khô năm 2019 2020, UBND tỉnh Bến Tre ban hành công văn số 496/UBND-KT (ngày 06/02/2020) gửi đến các sở ban ngành và UBND các huyện về việc tổ chức tổ chức thực hiện chỉ đạo của Trung ương về công tác phòng, chống hạn - mặn. Bên cạnh các văn bản chỉ đạo được ban hành từ UBND tỉnh Bến Tre, Đài Khí tượng Thuỷ văn tỉnh Bến Tre đã chủ động trình lên UBND tỉnh Bến Tre kế hoạch số 38/KH-ĐBT ngày 07/11/2019 về việc tăng cường đo đạc khí tượng thủy văn trong công tác phòng, chống thiên tai ứng phó biến đổi khí hậu năm 2020 nhằm chủ động trong công tác ứng phó xâm nhập mặn tại địa phương.

Kết quả tổng hợp các văn bản cho thấy UBND các huyện đã ban hành các kế hoạch phòng, chống và ứng phó xâm nhập mặn theo điều kiện thực tế của từng huyện. Cụ thể, Phòng NN\&PTNT có nhiệm vụ bảo trì, nâng cấp các công trình thủy lợi và phối hợp với Công ty trách nhiệm hữu hạn một thành viên Khai thác Công trình Thủy lợi tỉnh Bển Tre đưa ra các giải pháp về việc vận hành các công trình thủy lợi. Đồng thời Phòng NN\&PTNT cũng phối hợp với UBND các xã đưa ra các kế hoạch điều tiết nguồn nước phục vụ cho SXNN, theo dõi tình hình xâm nhập mặn thường xuyên để kịp thời để thông tin đến người dân địa phương; đưa ra các lịch thời vụ và hướng dẫn người dân các biện pháp kỹ thuật nhằm hạn chế thiệt hại trong SXNN và NTTS. UBND các xã có nhiệm vụ thực hiện các biện pháp phòng, chống xâm nhập mặn được chỉ đạo, theo dõi tình hình xâm nhập mặn tại địa phương để tham mưu cho việc chỉ đạo điều hành công tác ứng phó xâm nhập mặn có hiệu quả; tuyên truyền và vận động người dân chủ động thực hiện các biện pháp như đắp đập 
tạm, đê bao cục bộ, tự trang bị máy đo mặn; chỉ đạo Đài truyền thanh của các xã tuyên truyền công tác phòng, chống và ứng phó xâm nhập mặn và thông tin tình hình xâm nhập mặn cho người dân.

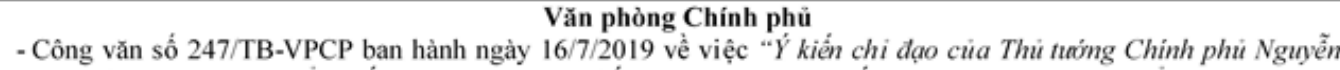

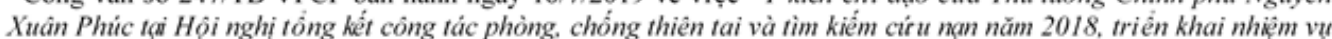
thò̀i gian tới"

- Chi thị số04/CT-TTg ban hành ngày 22/01/2020 về việc "Triển khai các giải pháp cấp bách phòng, chống hạn hán. thiếu mước, xâm nhàp măn"

\begin{tabular}{|c|c|}
\hline$\downarrow$ & 7 \\
\hline 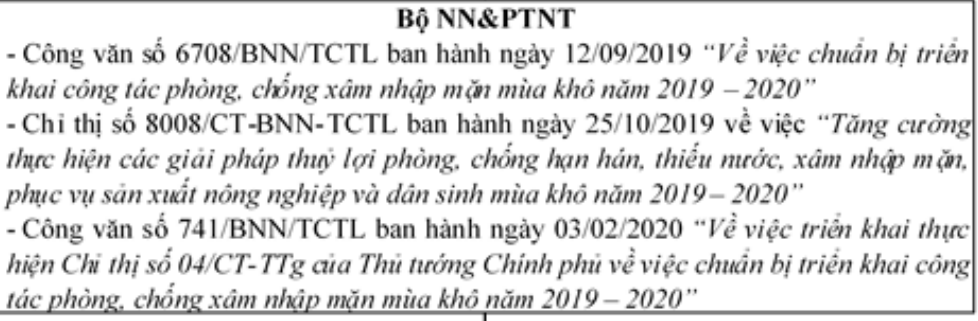 & 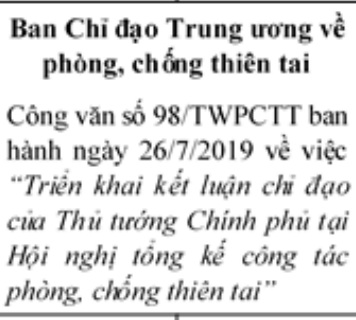 \\
\hline
\end{tabular}

\section{UBND tình Bến Tre}

- Công văn số 3613/UBND-KT ban hành ngày 25/7/2019 về việc "Tổ chíc thụcc hiện chỉ đạo cuia Thủ tướng Chinh phi vể công tác phòng, chống thiên tai"

-Công văn số 4028/UBND-KT ban hành ngày 15/8/2019 về việc "Tăng curờng thụcc hiộn các giải pháp trũ mước mura, mớc ngọt phưc vư sinh hoạt và sản xuất trong mùa khô năm 2019-2020"

- Kế hoạch số 4741/KH-UBND ban hành ngày 23/9/2019 về việc "Phòng chống thiếu mước, hạn hán, xâm nhập mặn mùa khô năm 2019 - 2020 trên địa bàn tỉnh Bến Tre"

- Công văn số 6208/UBND-KT ban hành ngày $11 / 12 / 2019$ vể việc "Phê duyệt kế hoạch tăng curờng đo đạc khí turợng thuý văn trong công tác phòng chống thiên tai năm 2020"

- Công văn số 6281/UBND-KT ban hành ngày 17/12/2019 về việc "Chỉ trương tăng cirơng đo mặn phục vụ công tác chỉ đạo, điè̀u hành, ìng phó xâm nhộp mặn"

-Quyết định số 72/QĐ-UBND ngày 13/01/2020 về việc "Tình huống khẩn cấp do xâm nhập mựn trên địa bàn tỉnh Bến Tre"

-Công văn số 496/UBND-KT ban hành ngày 06/02/2020 về việc "Tổ chíc thụcc hiện chỉ đạo cuia Trung trơng về công tác phòng, chống hạn mặn"

\begin{tabular}{|c|c|c|}
\hline$\downarrow$ & & $\downarrow$ \\
\hline UBND huyện Châu Thành & UBND huyện Gî̀ng Trôm & UBND huyện Thạnh Phú \\
\hline $128 /$ UBND-KT & - Kế hoạch số $2972 / \mathrm{KH}-\mathrm{UBND}$ ban & - Công văn số 19 PCTT ban hành ngày \\
\hline ban hành ngày $24 / 8 / 2019$ về việc & hành ngày $20 / 8 / 2019$ về việc "Phòng & 10/12/2019 về việc "Tăng curòng cảnh \\
\hline "Tăng cường tuyên truyền, vận & chống hán hán, thiếu mrớc, xâm nhập & giäc, khẩn trurơng thụrc hiện các biện pháp \\
\hline ậng trĩ mớc mura, nrớc ngot & mặn phục vụ sản xuất nông nghiệp và & i̛ng phó với tình hình độ mặn trên các sông \\
\hline phòng chống xâm nhập mạn trong & dân $\sinh$ năm 2019 - 2020 trên địa bàn & chinh đang tăng cao đột ngột và xâm nhập \\
\hline mùa khô năm 2019-2020" & huỵện Giồng Trôm" & sâu" \\
\hline - Kế hoạch số $4470 / \mathrm{KH}-\mathrm{UBND}$ & - Kế hoạch số $4210 / \mathrm{KH}-U B N D$ ban & - Công văn số 1291-CV/HU ban hành ngày \\
\hline ban hành ngày $06 / 12 / 2019$ về việc & hành ngày $03 / 12 / 2019$ về việc "Kháo & 30/12/2019 về việc "Khấn trương thụcc \\
\hline "Phòng chống xâm nhập măn & sát, đänh giả, hurớng dẫn chăm sóc cây & hiện các biện pháp phòng. chống và img \\
\hline mùa khô năm 2019 - 2020 trên & trồng, vậ nuôi, thiy sản trong điều kiện & phó với tình hình hạn hán, xâm nhập mặn " \\
\hline ậa bàn huyện Châu Thành" & hạn măn năm 2019" & - Kế hoạch số 83/KH-UBND ban hành \\
\hline - Công văn số $4495 /$ PCTT-TKCN & - Kế hoạch số $4353 / \mathrm{KH}-U B N D$ ban & ngày $14 / 01 / 2020$ về việc "Phòng, chống \\
\hline ban hành ngày $10 / 12 / 2019$ về việc & hành ngày $18 / 12 / 2019$ về việc "Kiểm & thi ấı nurớc, hạn hán và xâm nhập mặn năm \\
\hline "Cảnh báo tình hình xâm nhập & tra, đo nồng độ mặn tại các cống đầu & $2020^{\prime \prime}$ \\
\hline măn" & mối và khu vạc nội đồng trên địa bàn & - Công văn số 152-CV/BDVHU ban hành \\
\hline - Công văn số $2159 / \mathrm{CV}-\mathrm{HL}$ & hoyện" & ngày $19 / 02 / 2020$ về việc "Tuyên truyến \\
\hline hành ngày $16 / 01 / 2019$ về việc & - Kế họ̣ch số 02/KH-UBND ban hành & phòng chống, ting phó hạn mạn mùa khô \\
\hline "Tăng cường phòng chông, ting & ngày $02 / 01 / 2020$ về việc "Kiếm tra, đo & năm 2019 - 2020; vận động nhân dân trũ \\
\hline phó xâm nhập mặn mùa khố năm & nồng độ măn tại các cống đầu mối và & $\begin{array}{l}\text { mớc mura, miróc ngậ ph ục vu sinh hoạt và } \\
\text { sàn xuất"." }\end{array}$ \\
\hline 2019 & & \\
\hline
\end{tabular}

Hình 5. Sơ đồ văn bản chỉ đạo phòng, chống và ứng phó xâm nhập mặn mùa khô năm 2019 - 2020

(Nguồn: Kết quả tổng hợp các văn bản năm 2020) 


\subsection{2. Đánh giá thực trạng phối hợp của các bên trong công tác ứng phó xâm nhập mặn}

Trong công tác ứng phó xâm nhập mặn mùa khô năm 2019 - 2020 tại tỉnh Bến Tre, Sở TN\&MT đã phối hợp với Đài Khí tượng Thuỷ văn tỉnh Bến Tre đã đưa ra các bản tin dự báo độ mặn, tóm tắt tình hình xâm nhập mặn trên địa bản tỉnh Bến Tre hàng tuần trên trang thông tin điện tử giúp các cơ quan và người dân theo dõi tình hình diễn biến xâm nhập mặn một cách dễ dàng hơn. Nhằm hạn chế những thiệt hại và để người dân nắm bắt thông tin kịp thời cũng như thích ứng với biến đổi khí hậu, Đài Khí tượng Thuỷ văn tỉnh Bến Tre đã kết hợp với Chi cục Thủy lợi tỉnh Bến Tre và Sở Khoa học và Công nghệ tỉnh Bến Tre xây dựng trang web (https://thuyloibentre.com/) quản lý thông tin về công trình thủy lợi, dữ liệu thủy văn và cảnh báo, dự báo xâm nhập mặn trên địa bàn tỉnh nhằm cảnh báo tình hình xâm nhập mặn một cách liên tục và kịp thời, nhằm hỗ trợ người dân dễ dàng tiếp cận tin tức, chủ động trong việc lấy nước ngọt phục vụ cho việc SXNN và sinh hoạt. Sở NN\&PTNT được giao nhiệm vụ phối hợp với Sở Khoa học và Công nghệ triển khai ứng dụng khoa học công nghệ trong sản xuất như: tưới tiêu tiết kiệm hiệu quả, tăng khả năng thích ứng và chống chịu mặn ở cây trồng - vật nuôi; đồng thời Sở NN\&PTNT cũng phối hợp với Công ty cổ phần cấp thoát nước Bến Tre cấp nước cho người dân địa phương. Bên cạnh đó, Sở NN\&PTNT còn phối hợp với Công ty trách nhiệm hữu hạn Một thành viên Khai thác Công trình Thủy lợi thực hiện giải pháp về công trình trên địa bàn tỉnh.

Phòng NN\&PTNT các huyện đã phối hợp với UBND các xã khảo sát, đắp đập ngăn mặn cục bộ; đồng thời Phòng cũng phối hợp với Trạm Khuyến nông và Trạm Bảo vệ thực vật triển khai các giải pháp nhằm nâng cao khả năng thích ứng cho cây trồng như kỹ thuật tưới tiết kiệm, kỹ thuật chăm sóc cây thích ứng hạn mặn tại địa phương, cũng như phối hợp Trạm Thủy nông quan trắc độ mặn tại các cống đầu mối và đưa ra lịch vận hành cống phù hợp, thông tin kịp thời đến các cơ quan chức năng và người dân địa phương (Kết quả khảo sát, 2020).

Thông qua nội dung và thời gian ban hành các văn bản chỉ đạo công tác ứng phó xâm nhập mặn mùa khô năm 2019 - 2020 theo trình tự từ Trung ương đến địa phương cho thấy, các văn bản dự báo, cảnh báo về xâm nhập mặn và các văn bản chỉ đạo công tác ứng phó xâm nhập mặn đã được ban hành kịp thời trước khi xâm nhập mặn diễn ra tại địa phương, giúp các cơ quan chủ động được trong công tác ứng phó xâm nhập mặn. Các cơ quan đã thực hiện theo đúng nhiệm vụ được giao trong các văn bản chỉ đạo. Tuy nhiên, Kế hoạch phòng, chống và ứng phó xâm nhập mặn mùa khô năm 2019 - 2020 từ UBND huyện Thạnh Phú được ban hành vào tháng 01/2020 chưa đạt được kịp thời so với Kế hoạch số 4741/KH-UBND (ngày 29/09/2019) từ UBND tỉnh Bến Tre theo TCVN ISSO 9001:2015 về mặt thời gian ban hành văn bản (văn bản phải được ban hành trước 45 ngày kể từ khi có văn bản chỉ đạo từ cấp trên) và chưa đạt được kịp thời về mặt thực tế khi xâm nhập mặn đã diễ் ra trên địa bàn huyện từ tháng 11/2019.

Các bên liên quan đã có sự phối hợp với nhau trong công tác ứng phó xâm nhập mặn như văn bản được giao. Tuy nhiên, sự phối hợp giữa các bên liên quan ở cùng cấp tại các huyện còn nhiều hạn chế do nhiệm vụ của các bên liên quan được giao trong các văn bản chỉ đạo ứng xâm nhập mặn mặn tại các huyện còn độc lập (Kế hoạch số 2972/KH-UBND huyện Giồng Trôm, Kế hoạch số 83/KH-UBND huyện Thạnh Phú). Các cơ quan chức năng chỉ phối hợp khi có văn bản chỉ đạo từ cấp trên do đó chưa thây được sự phối hợp chặt chẽ giữa các đơn vị cùng cấp huyện, đặc biệt là giữa Phòng NN\&PTNT và Phòng TN\&MT. Các kế hoạch được ban hành vẫn chưa quy định rõ ràng sự phối hợp ở các đơn vị cùng cấp huyện, văn bản chỉ nêu lên việc một cơ quan phối hợp với các cơ quan có liên quan mà chưa nêu cụ thể phối hợp với cơ quan nào (Kế hoạch số 83/KH-UBND huyện Thạnh Phú). Bên cạnh đó, nghiên cứu của Nguyen et al., (2021) tại Bến Tre cũng cho thấy rằng vai trò và trách nhiệm của các bên trong công tác ứng phó với xâm nhập mặn vẫn còn gây nhầm lẫn và chưa rõ ràng, điều này có thể dẫn đến việc thực thi công tác ứng phó xâm nhập mặn không hiệu quả trong các trường hợp khẩn cấp.

\section{KẾT LUẬN VÀ KIẾN NGH!}

Qua kết quả nghiên cứu, xâm nhập mặn mùa khô năm 2019 - 2020 diễn ra gay gắt hơn xâm nhập mặn mùa khô năm 2015 - 2016 về mặt không gian, gây nhiều thiệt hại đến SXNN và NTTS tại địa phương. Trước tác động từ các đợt xâm nhập mặn cực đoan mùa khô năm 2015 - 2016 và năm 2019 - 2020, việc sử dụng đất đai tại khu vực nghiên cứu đã có sự chuyển dịch nhằm thích ứng với xâm nhập mặn. Công tác chỉ đạo phòng, chống và ứng phó xâm nhập mặn mùa khô năm 2019 - 2020 được kịp thời từ cấp Trung ương đến địa phương giúp người dân chủ động trong việc ứng phó xâm nhập mặn. Sự phối hợp giữa các bên liên quan trong công tác ứng phó xâm nhập mặn tại địa phương được quy định rõ ràng 
và thực hiện theo chiều dọc (từ trung ương đến địa phương). Tuy nhiên, sự phối hợp theo chiều ngang giữa các bên còn gặp nhiều hạn chế khi sự phối hợp giữa các cơ quan cùng cấp chưa được quy định rõ ràng trong các văn bản chỉ đạo ứng phó xâm nhập mặn tại địa phương.

Nghiên cứu là bước đầu đánh giá hiệu quả công tác ứng phó với xâm nhập mặn trong điều kiện thời tiết cực đoan tại vùng ven biển ĐBSCL. Nghiên cứu chỉ tập trung đánh giá công tác ứng phó trước và trong khi xảy ra xâm nhập mặn mà chưa xem xét đến các giải pháp làm giảm thiệt hại sau khi đợt xâm nhập mặn diễn ra và nghiên cứu chưa đánh giá được hết các nguyên tắc trong nhóm hiệu quả của $\mathrm{OECD}$, còn hạn chế trong việc đánh giá cơ chế phối hợp theo chiều ngang ở cấp Tỉnh và cấp Trung ương. Vì thế nhóm tác giả đề xuất cần có các nghiên cứu đánh giá toàn diện hơn về hiệu quả của công tác ứng phó xâm nhập mặn, nhằm hổ trợ việc quy hoạch và phát triển bền vững tài nguyên nước, đặc biệt trong điều kiện thời tiết ngày càng bất thường.

\section{LỜI CẢM ƠN}

Nghiên cứu này được tài trợ bởi Dự án Nâng cấp Trường Đại học Cần Thơ VN14-P6 bằng nguồn vốn vay ODA từ Chính phủ Nhật Bản.

\section{TÀI LIỆU THAM KHẢO}

Dutch WASH Alliance. (2014). FIETS Sustainability Approach.

Giáp Văn Vinh. (2020). Tình Hình Thủy Văn và Xâm Nhập Mặn Năm 2020 ở ĐBSCL. Hội Thảo về Hạn - Mặn Năm 2020 ở Đồng Bằng Sông Cửu Long, ngày 17 tháng 06 năm 2020, Viện Nghiên Cứu Biến Đổi Khí Hậu, Trường Đại học Cần Thơ.

Intergovernmental Panel on Climate Change. (2014). Climate Change 2014 Part A: Global and Sectoral Aspects.

Jakob, C., \& Khemka, R. (2017). Vietnam: HydroEconomic Framework for Assessing Water
Sector Challenges. 2030 Water Resources Group. World Bank.

Le, T. N., Bregt, A. K., van Halsema, G. E., Hellegers, P. J., \& Nguyen, L. D. (2018). Interplay between land-use dynamics and changes in hydrological regime in the Vietnamese Mekong Delta. Land Use Policy, 73, 269-280.

Nguyen, M. N., Nguyen, P. T., Van, T. P., Phan, V. H., Nguyen, B. T., Pham, V. T., \& Nguyen, T. H. (2021). An understanding of water governance systems in responding to extreme droughts in the Vietnamese Mekong Delta. International Journal of Water Resources Development, 37(2), 256-277.

OECD. (2015). OECD Principles on Water Governance.

Phan Hoàng Vũ, Phạm Thanh Vũ \& Văn Phạm Đăng Trí. (2016). Phân Vùng Rủi Ro Trong Sản Xuất Nông Nghiệp Dưới Tác Động Của Xâm Nhập Mặn ở Tỉnh Bạc Liêu. Tạp chi Khoa học Truờng Đại Học Cần Tho , 42, 70-80.

Van Rijswick, M., Edelenbos, J., Hellegers, P., Kok, M., \& Kuks, S. (2014). Ten building blocks for sustainable water governance: an integrated method to assess the governance of water. Water international, 39(5), 725-742.

Ryan, F., Coughlan, M., \& Cronin, P. (2009). Interviewing in qualitative research: The one-toone interview. International Journal of Therapy and Rehabilitation, 16(6), 309-314.

Ủy ban Dân tộc. (2019). Quyết Định về áp dụng tài liệu hệ thống quản lý chất lượng theo tiêu chuẩn quốc gia TCVN ISO 9001:2015 tại Cơ quan Ủy ban Dân tộc (Số 887/QĐ-UBDT).

Viện Khoa học Thuỷ lợi miền Nam. (2019). Báo cáo dự báo nguồn nước, xâm nhập mặn mùa khô năm 2019 - 2020 vùng Đồng bằng sông Cửu Long và đề xuất giải pháp chống hạn.

World Bank. (2019). Vietnam: Toward a safe, clean, and resilient water system. World Bank. Washington, DC. 